\title{
Procedure optimization for green synthesis of manganese dioxide nanoparticles by Yucca gloriosa leaf extract
}

\author{
Mahsa Souri $^{1} \cdot$ Vahid Hoseinpour $^{1}$ (D) $\cdot$ Nasser Ghaemi ${ }^{1} \cdot$ Alireza Shakeri $^{1}$
}

Received: 21 April 2018 / Accepted: 3 December 2018 / Published online: 7 December 2018

(c) The Author(s) 2018

\begin{abstract}
In this paper, a simple, efficient, and eco-friendly procedure for the green synthesis of manganese dioxide nanoparticles $\left(\mathrm{MnO}_{2} \mathrm{NPs}\right)$ by Yucca gloriosa leaf extract is described. The effect of three different factors such as $\mathrm{pH}$ of the metallic solution, time, and extract ratio was studied. Optimizing the factors was done by Response Surface Methodology (RSM). Considering the results, the ratio of the extract to the metallic solution and the time was the most important factors for the synthesis of $\mathrm{MnO}_{2}$ NPs. The optimal condition was claimed to be time $=120 \mathrm{~min}, \mathrm{pH}$ 6, and extract ratio $=90 \%$. Then, the $\mathrm{MnO}_{2} \mathrm{NPs}$ re-synthesized using $Y$. gloriosa leaf extract and stabilized using turmeric extract. Crystal phase identification of the $\mathrm{MnO}_{2} \mathrm{NPs}$ was characterized by XRD analysis and the formation of crystalline $\mathrm{MnO}_{2}$ has been confirmed. In addition, XRD study confirms the attendance of $\mathrm{MnO}_{2} \mathrm{NPs}$ with around size of $32 \mathrm{~nm}$. Furthermore, FESEM and TEM analyses showed that the synthesized $\mathrm{MnO}_{2} \mathrm{NPs}$ have the spherical shape.
\end{abstract}

Keywords Nanoparticle $\cdot$ Green synthesis $\cdot$ Yucca gloriosa $\cdot$ Optimization $\cdot$ RSM

\section{Introduction}

In the field of nanoparticle synthesis from different materials, notable improvements have recently been accomplished and lots of effort have been done to control their size, composition, and uniformity [1]. Nanoscales' materials have raised as novel antibacterial agents comprising a great ratio of surface area to volume and the unique physical and chemical properties $[2,3]$. Nanoparticles display exclusive physicochemical attributes contrasted with their bulk materials. There is a considerable keen on obtaining well-diffused, ultrafine, and monotonous nanoscales to delineate and take their distinct distinguished [4]. Metallic nanoscales, like nanomaterials, have attracted much interest in academia

Vahid Hoseinpour

vahidhoseinpur@ut.ac.ir

Mahsa Souri

souri.mahsa@ut.ac.ir

Nasser Ghaemi

nasser.ghaemi@khayam.ut.ac.ir

Alireza Shakeri

alireza.shakeri@ut.ac.ir

1 School of Chemistry, College of Science, University of Tehran, Tehran, Iran and engineering because of their physicochemical properties [5]. Mn oxides can be employed in molecular sieves, solar cells, optoelectronics, drug delivery ion sieves, as well as other fields such as imaging contrast agents, magnetic storage devices, and water treatment and purification, due to their privileged physical and chemical properties [4, 6-11].

Various methods including chemical and physical means, chemical reduction, sol-gel, solvothermal or hydrothermal, and electrochemical reduction techniques are widely employed for the synthesis of the nanomaterials $[12,13]$. Their available synthetic processes include either oxidation of $\mathrm{Mn}(\mathrm{II})$ in basic solution or oxidation by oxygen, potassium persulfate, and hydrogen peroxide, or by reduction of permanganate using different routes [14, 15]. Eventually, synthesize of nanoscales has been done by bacteria, fungi, and other microorganisms $[12,16,17]$. The menace of growing contamination causes a great request for green chemistry and biological processes for preparation, recycling, and degrading chemical materials [18]. The synthesis of nanomaterials using plants extracts can be preferable than other biological methods like microbial procedure [18, 19]. Antioxidant activity of the plant's extracts is responsible for synthesizing of metallic nanomaterials. The usage of the extract of Parthenium [20], Euphorbia hirta, Polyalthia longifolia [21], Coriandrum sativum, Dittrichia graveolens (L.) [10, 
22] Azadirachta indica, Jatropha curcas [23], Ocimum sanctum, and several other plants supply the principles of green chemistry that is environmentally friendly. This reaction is safe, quick, and easily done at the ambient temperature and pressure, and can be scaled-up easily [21]. Early researchers of Yucca gloriosa bark yielded two Yucca species of tropical or subtropical plants with a tree-like habit, which grow mainly in the arid or semi-arid regions. They contain large quantities of steroidal glycosides. They thus have potential in biological, pharmaceutical, and industrial applications and several steroidal glycosides exhibit fungistatic or fungicidal property [24]. In addition, they contain several very uncommon phenolic constituents named gloriosaols A, B, $\mathrm{C}, \mathrm{D}$, and E [25]. The Trolox equivalent antioxidant capacity (TEAC) assay confirmed the remarkable antioxidant activity of the Y. gloriosa extract [25], which have made it useful for the synthesis of the nanoparticles [14].

In this study, manganese nanoscales are prepared via the Y. gloriosa leaves extract, optimized, and evaluated by the design expert software. RSM as a cost-effective and timesaving method [26] was used for optimization. $\mathrm{MnO}_{2} \mathrm{NPs}$ characterized via XRD and FESEM, and TEM analysis methods.

\section{Experimental}

\section{Materials}

Manganese acetate $\left[\left(\mathrm{CH}_{3} \mathrm{COO}\right)_{2} \mathrm{Mn} \cdot 6 \mathrm{H}_{2} \mathrm{O}\right]$ the analytical grade was purchased from Sigma-Aldrich company (USA). Fresh leaves of $Y$. gloriosa were cut from University of Tehran campus (Tehran, Iran); leaves thoroughly washed thrice with distilled water and air-dried in the shade. All chemicals and solvents were used as received without further purification and distilled water was used in all experiments.

\section{Optimization of green synthesis}

\section{Green synthesis of the $\mathrm{MnO}_{2} \mathrm{NPs}$}

$8 \mathrm{~g}$ dried powder of $Y$. gloriosa was boiled for $5 \mathrm{~min}$ in an Erlenmeyer flask comprising $200 \mathrm{~mL}$ of distilled water. The combination was chilled and centrifuged at $3500 \mathrm{rpm}$ for $15 \mathrm{~min}$. The supernatant was collect in a colored bottle and stored at $4{ }^{\circ} \mathrm{C}$. To synthesize the $\mathrm{MnO}_{2} \mathrm{NPs}$, different ratios $(10,25$, and 50\%) of $Y$. gloriosa leaf extract and the aqueous solution of $0.01 \mathrm{mM}$ manganese acetate $\left[\left(\mathrm{CH}_{3} \mathrm{COO}\right)_{2} \mathrm{Mn} \cdot 6 \mathrm{H}_{2} \mathrm{O}\right]$ at different $\mathrm{pH}(4,6$, and 8) were mixed and stirred at room temperature for various times $(40,80$, and $120 \mathrm{~min})$. The precipitates were obtained by centrifuging of each sample, washed using distilled water and ethanol several times, and suspended in $7 \mathrm{~mL}$ distilled
Table 1 Experimental planning

\begin{tabular}{llllll}
\hline Std & Run & $\begin{array}{l}\text { Factor 1 } \\
A \text { : time, min }\end{array}$ & $\begin{array}{l}\text { Factor 2 } \\
B: \mathrm{pH}\end{array}$ & $\begin{array}{l}\text { Factor 3 } \\
C \text { : extract, \% }\end{array}$ & $\begin{array}{l}\text { Response 1 } \\
\text { Absorbance }\end{array}$ \\
\hline 8 & 1 & 40 & 4 & 50 & 0.1231 \\
4 & 2 & 40 & 6 & 25 & 0.0518 \\
2 & 3 & 40 & 8 & 10 & 0.0187 \\
1 & 4 & 80 & 4 & 25 & 0.0586 \\
5 & 5 & 80 & 6 & 10 & 0.0185 \\
3 & 6 & 80 & 8 & 50 & 0.0952 \\
7 & 7 & 120 & 4 & 10 & 0.0564 \\
9 & 8 & 120 & 6 & 50 & 0.4750 \\
6 & 9 & 120 & 8 & 25 & 0.1972 \\
\hline
\end{tabular}

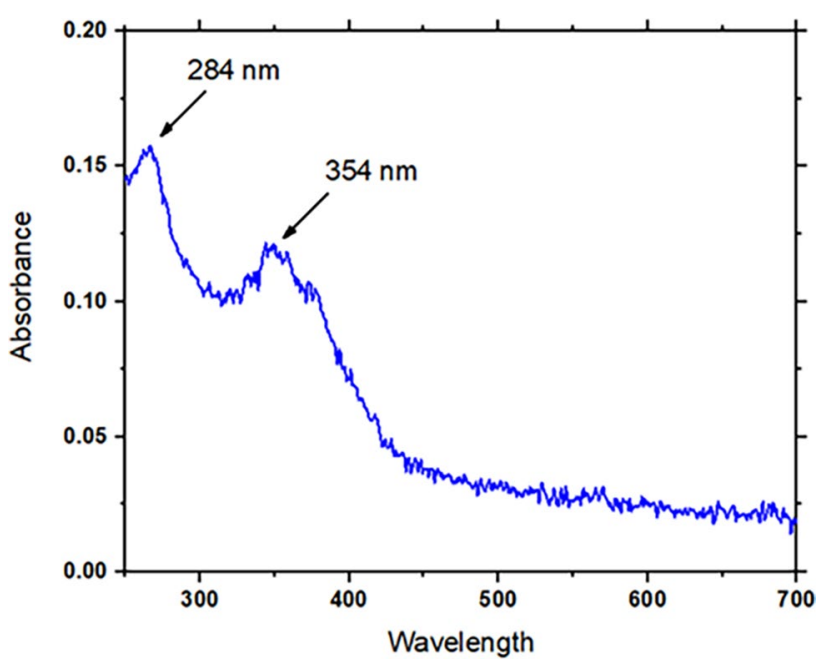

Fig. 1 UV-Vis spectroscopy of synthesized $\mathrm{MnO}_{2} \mathrm{NPs}$ at Run 1

water for UV-Vis spectra analysis. 9 runs were designed using Design Expert 10 to survey the effect of $\mathrm{pH}$, the metal aqueous solution-to-extract ratio (v/v), and time (Table 1), the formation of $\mathrm{MnO}_{2} \mathrm{NPs}$ was monitored via recording $\mathrm{UV}-\mathrm{Vis}$ spectroscopy. The UV-Vis spectrum of run 1 is shown in Fig. 1.

\section{Statistical analysis}

RSM is a statistical method that uses quantitative data from suitable experiments to define regression model equations and operating conditions [27]. This is generally accomplished by performing a prior screening design to define which of the experimental variables and their interactions present more significant effects. Certainly, there are numerous variables that may affect the response of a system, and it is practically inconceivable to identify and control all of them [28]. In this research, the statistical 
design of the response surface was chosen to study the main effects of the factors and their interactions [22].

In the RSM, for each dependent variable, one model is defined which states the main and mutual effects of the factors on each variable singly. In this research, the design with three variables including the time $(40,60$, and $120 \mathrm{~min})$, plant extract ratio $(25,50$ and $75 \% \mathrm{v} / \mathrm{v})$, and $\mathrm{pH}(4,6$, and 8$)$ was used to optimize the synthesis of the $\mathrm{MnO}_{2}$ NPs to obtain the higher yield.

\section{Characterization of the $\mathrm{MnO}_{2} \mathrm{NPs}$}

$16 \mathrm{~g}$ powdered turmeric was placed in a flask containing $400 \mathrm{~mL}$ of ethanol and boiled for $5 \mathrm{~min}$. The cooled mixture was centrifuged at $3500 \mathrm{rpm}$ for $15 \mathrm{~min}$. The clear supernatant was stored at $4{ }^{\circ} \mathrm{C} .20 \mathrm{~mL} 0.01 \mathrm{mM}$ manganese acetate $\left[\left(\mathrm{CH}_{3} \mathrm{COO}\right)_{2} \mathrm{Mn} \cdot 6 \mathrm{H}_{2} \mathrm{O}\right]$, and the aqueous solution at $\mathrm{pH} 8$ was mixed with $180 \mathrm{~mL}$ leaf extract (extract ratio $90 \%$ ) for $60 \mathrm{~min}$ and stirred at room temperature. In this step, $20 \mathrm{~mL}$ turmeric which contains bio-active curcumin added to the solution. This curcumin extract was employed as a stabilizer for $\mathrm{MnO}_{2} \mathrm{NPs}$ [9]. The obtained solution was centrifuged and the precipitate was collected and washed with deionized water and ethanol several times, and the precipitate was collected, washed, and dried for XRD, TEM, and FESEM analyses.

\section{Results and discussion}

\section{Statistical analysis}

The reduction of $\mathrm{Mn}$ ions to manganese dioxide nanoparticles $\left(\mathrm{MnO}_{2} \mathrm{NPs}\right)$ for run 1 was spectrometrically identified by double beam UV-Vis spectrophotometer (Perkin Elmer, Lambda 850) at a different wavelength (200-700 nm). The absorption spectra of the synthesized sample are shown in Fig. 1. The samples show two sharp absorption peaks at 284 and $354 \mathrm{~nm}$ each of which is related to the bandgap absorption of the $\mathrm{MnO}_{2}$ NPs. It should be noted that the absorbance peak of $\mathrm{MnO}_{2} \mathrm{NPs}$ sol also changed [29]. The absorbance peak at 284 and $254 \mathrm{~nm}$ shows the absorption and transmission spectra of the $\mathrm{MnO}_{2}$ NPs sols with various impurities [29]. The $\mathrm{MnO}_{2}$ NPs showed absorption maxima at $284 \mathrm{~nm}$. Based on the above discussions at the second section of an experiment a stabilizing agent, curcumin extracted from turmeric was used for preventing the $\mathrm{MnO}_{2}$ NPs from the accumulation [9]. The absorbance peaks at $284 \mathrm{~nm}$ are reported in Table 1.
Table 2 Model summary statistics

\begin{tabular}{lrlc}
\hline Std. dev. & 0.10 & $R$-squared & 0.7808 \\
Mean & 0.31 & Adj $R$-squared & 0.6493 \\
C.V. \% & 33.32 & Pred $R$-squared & 0.2177 \\
PRESS & 0.19 & Adeq precision & 7.062 \\
-2 Log likelihood & -20.72 & BIC & -11.94 \\
& & AICc & -2.72 \\
\hline
\end{tabular}

\section{Evaluation of the fitted model}

For fitting the model, different statistical analysis methods are engaged to advise the experimental error, the compatibility of the model, and statistical significance of the qualifications in the model. This is generally done with the aid of an RSM program [30]. Critical evaluation of the quality of the fitted model is by the application of analysis of variance (ANOVA). The principle thought ANOVA is to contrast the variation owing to the behavior with the variation due to random errors innate to the mensuration of the generated responses [31]. The ultimate model can be employed to make a graphical display of parameter dependency.

\section{Experimental design}

To study the effect of the parameters: time, $\mathrm{pH}$, and extract ratio of the synthesis progress, experiments were carried out using I-optimal Coordinate Exchange Design. The effect of the three variables studied by means of accomplishing nine different experiments. The responses obtained by the measuring adsorption of the $\mathrm{MnO}_{2} \mathrm{NPs}$ at $353 \mathrm{~nm}$ and the polynomial second-degree equation for each factor are as follows:

Final equation in terms of coded factors:

$$
\begin{aligned}
\text { Absorbance }= & +(0.59+0.11) \times A+(9.825 \mathrm{E}-003) \\
& \times B+0.14 \times C .
\end{aligned}
$$

Final equation in terms of actual factors:

$$
\begin{aligned}
\text { Absorbance }= & -0.13444+(2.73150 \mathrm{E}-003) \times \text { time } \\
& +(4.91231 \mathrm{E}-003) \times \mathrm{pH} \\
& +(6.86504 \mathrm{E}-003) \times \text { extract },
\end{aligned}
$$

where $A, B$, and $C$ represent the initial time, $\mathrm{pH}$, and extract ratio, respectively. Multiple interactions are seen between the two factors. Equations (1) and (2) demonstrate that the extract ratio was the most influential parameter with a positive effect on absorbance, and then, time also $\mathrm{pH}$ did not have many positive effects. 
The results of each experience carried out by the software are shown in Table 1.

\section{Variance analysis}

The ANOVA (Tables 2, 3) showed that the equation is very indicative of the real communication between the response (the adsorption at $284 \mathrm{~nm}$ ) and the significant variables. There is communication between the observed and predicted values as displayed by closeness between $R^{2}$ and adjusted $R^{2}$ value which is one (Table 2). The result demonstrates that the regression model caters a description of the communication between the independent factors and adsorption. The model is considered to be statistically significant, since the associated Prob. $>F$ value for the model is lower than 0.05 (Table 3) [32].

\section{Effect parameters}

UV-Vis experiences were carried out by the chosen model with a selected range of $\mathrm{pH}$ and time to check the composed effect of the $\mathrm{pH}$ and time values on the system. RSM was used and results were given in the form of 3D and contours plots. Figure $2 \mathrm{a}$, b displays that if time increases from 40 to $120 \mathrm{~min}$ and extract ratio remains at $70 \%$, absorbance will increase from about 0.2 to about 0.45 . The optimum value of both the factors including time and $\mathrm{pH}$ can be analyzed by checking the maximum formed by $X$ and $Y$ coordinates. Time has a specific positive effect on absorbance.

Figure $3 \mathrm{a}, \mathrm{b}$ shows the effect of extract ratio and $\mathrm{pH}$ on the absorbance value under the pre-defined status given by the model. This chart shows that the maximum absorbance $(0.58)$ happens at the extract ratio of $90 \%$, which means that it is in agreement with the model. Increasing the extract ratio to the metal solution to $90 \%$ rises the absorbance, which clearly means that the number of effective materials of the plant has the greatest effect on $\mathrm{MnO}_{2}$ NPs' synthesis.

The combined effect of the time and extract ratio has been analyzed (Fig. 4a, b) and it has been computed that as the time augments from 40 to $120 \mathrm{~min}$, maintaining $\mathrm{pH}$ at 6.0 and increasing the extract ratio to $90 \%$, absorbance increases to 0.65 . This clearly shows that the ratio
Table 3 Analysis of variance table [partial sum of squarestype III]

\begin{tabular}{lllllll}
\hline Source & Sum of squares & $d f$ & Mean square & $F$ value & $\begin{array}{l}p \text { value } \\
\text { Prob }>F\end{array}$ \\
\hline Model & 0.19 & 3 & 0.063 & 5.94 & 0.0421 & Significant \\
A-time & 0.072 & 1 & 0.072 & 6.80 & 0.0478 & \\
B-pH & $5.791 \mathrm{E}-004$ & 1 & $5.791 \mathrm{E}-004$ & 0.055 & 0.8239 & \\
C-extract & 0.12 & 1 & 0.12 & 10.96 & 0.0212 & \\
Residual & 0.053 & 5 & 0.011 & & & \\
Cor Total & 0.24 & 8 & & & & \\
\hline
\end{tabular}
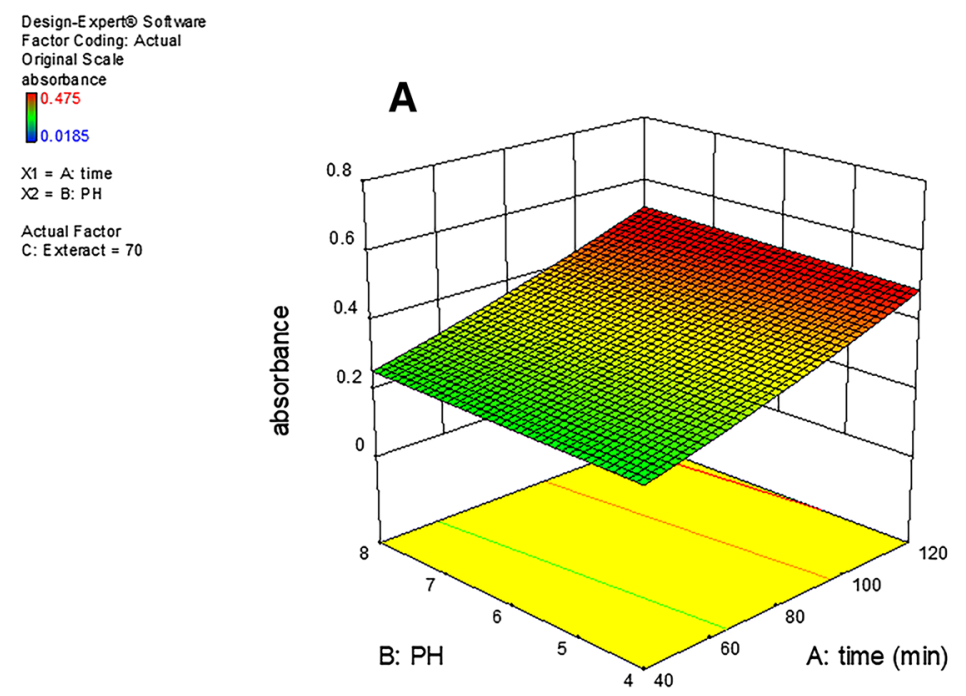

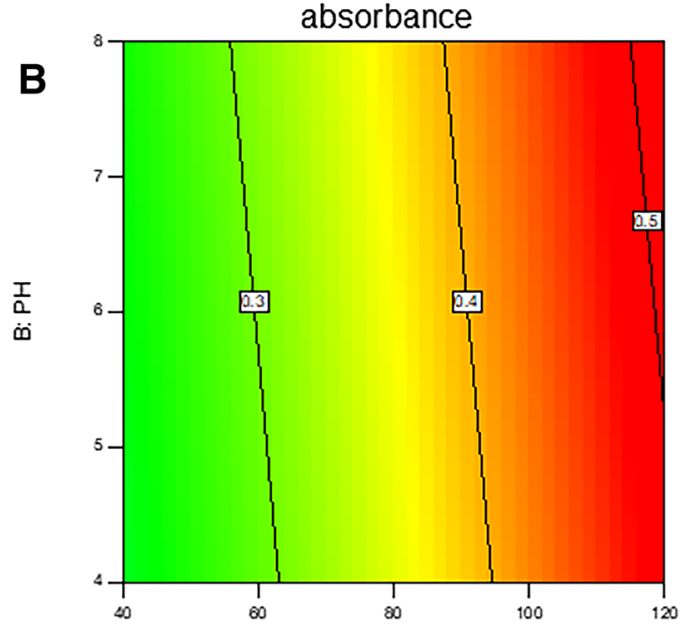

A. time (min)

Fig. 2 Contour plot (a) and 3D plot (b) displaying the effect of time and $\mathrm{pH}$ on absorbance 
Design-Experte Sotware

Factor Coding: Actu

Original Scale

- Design points below precicted value

$\overbrace{}^{0.475}$

10.0185

$\mathrm{X}_{1}=\mathrm{C}:$ Extrac:

$\mathrm{CQ}=\mathrm{B}: \mathrm{PH}$

Aetual Facto
A: time $=80$

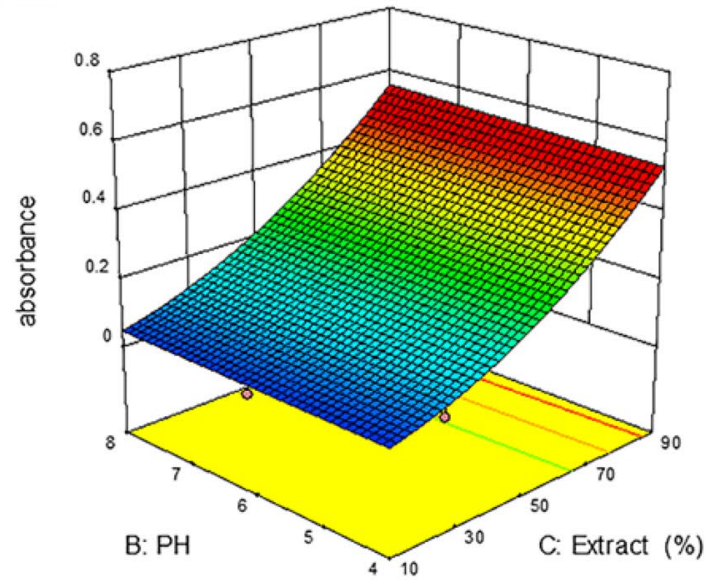

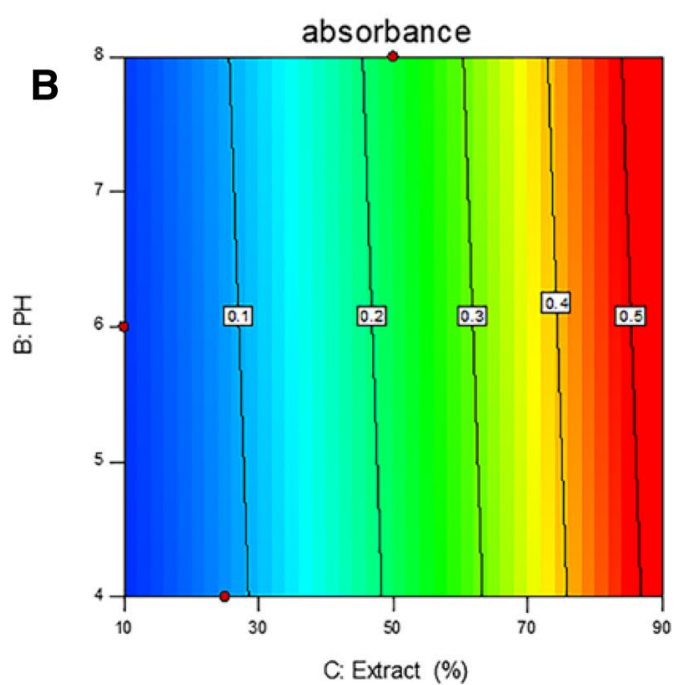

Fig. 3 Contour plot (a) and 3D plot (b) displaying the effect of extract ratio and $\mathrm{pH}$ on absorbance
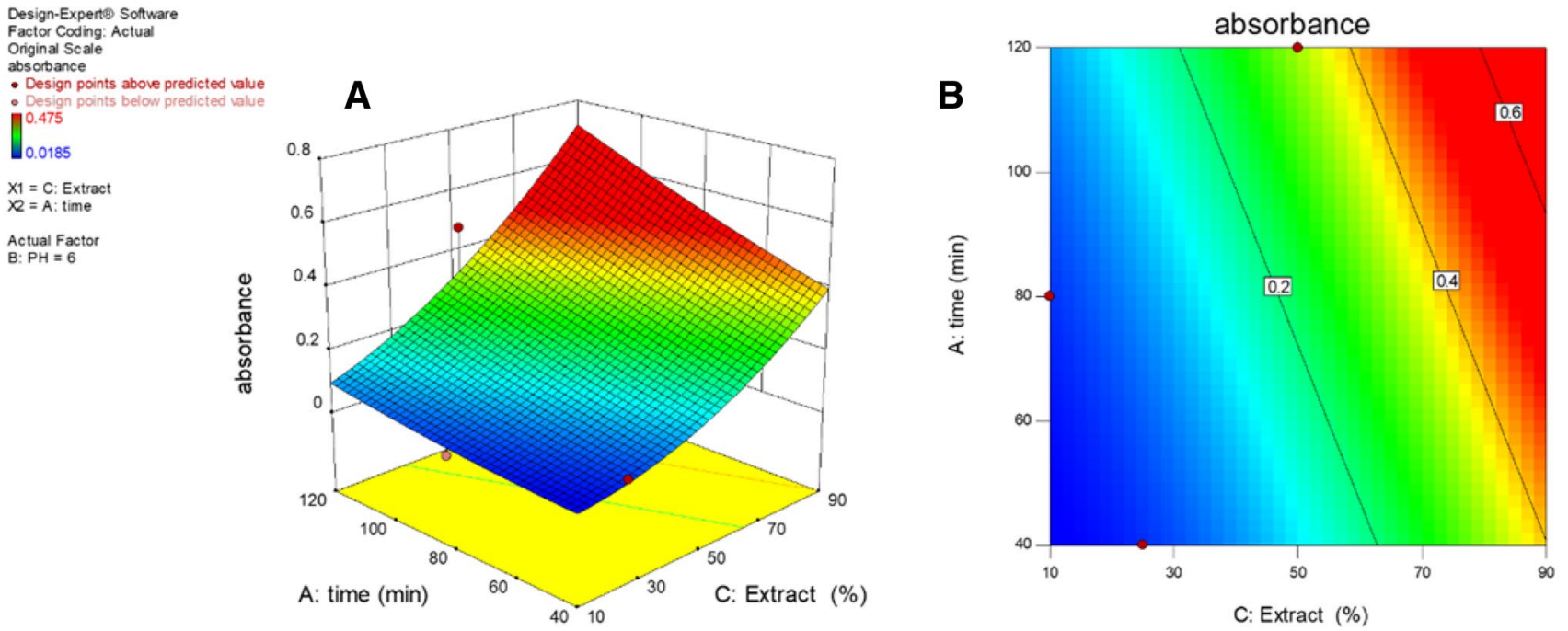

Fig. 4 Contour plot (a) and 3D plot (b) displaying the effect of extract ratio and time on absorbance

of extract and time is the most important factors for the synthesis of nanomaterials.

\section{Characterization of $\mathrm{MnO}_{2} \mathrm{NPs}$}

\section{XRD analysis}

X-ray diffraction (XRD) studies of synthesized NCs were carried out at room temperature with an X-ray diffract meter (PANalytical, X' Pert Pro) using $\mathrm{Cu} \mathrm{K} \alpha$ radiation. XRD pattern of $\mathrm{MnO}_{2}$ NPs (Fig. 5) displays a broad pattern which has been associated with bio-capped and amorphous materials in $\mathrm{MnO}_{2}$ NPs [33]. Diffraction peaks appeared at $2 \theta$ values of $20.9965^{\circ}, 26.8411^{\circ}, 36.5673^{\circ}, 39.7091^{\circ}, 41.4953^{\circ}$, $42.4683^{\circ}$, and $68.0813^{\circ}$ reflections can be indexed to the known orthorhombic structure of $\mathrm{MnO}_{2}$ with lattice constants of $a=9.5160 \AA, b=2.8640 \AA, c=4.7060 \AA$, and $\alpha=\beta=\gamma=90.0000^{\circ}$ (COO-213 card, no. 96-900-3477). The sharp XRD peaks clearly show that $\mathrm{MnO}_{2}$ NPs were synthesized with suitable purity. The XRD pattern display extra peak of low importance, marked with (o). This may be due to the formation of crystalline compounds that are present in the plant extracts [34]. The average size of the $\mathrm{MnO}_{2}$ nanoparticles was determined via Debye-Scherrer equation $d=(k \lambda / \beta \cos \theta)$, where $\mathrm{k}$ is the Debye-Scherrer constant (0.89), $\lambda$ is the $\mathrm{X}$-ray wavelength $(0.154 \mathrm{~nm}), \beta$ is the width 


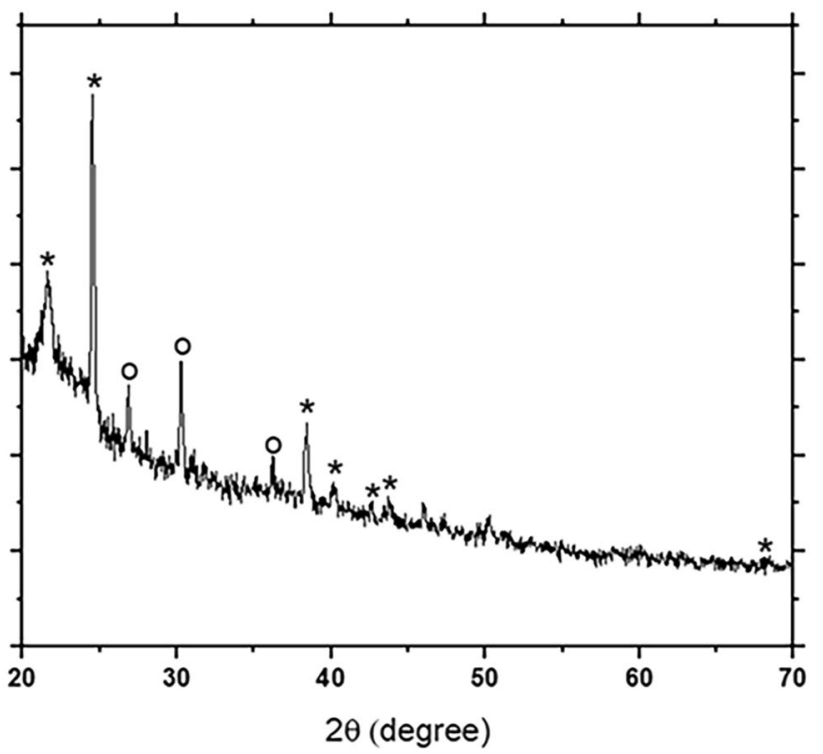

Fig. 5 XRD pattern of synthesized $\mathrm{MnO}_{2}$ NPs

Table 4 Comparison of size of Mn NP in different works

\begin{tabular}{lll}
\hline Plant used & Size & References \\
\hline Lemon methanolic extract & $50 \mathrm{~nm}$ & {$[9]$} \\
Kalopanax pictus leaf extract & $1-60 \mathrm{~nm}$ & {$[4]$} \\
Clove, i.e., Syzygium aromaticum & $4 \mathrm{~nm}$ & {$[7]$} \\
$\quad$ aqueous extract & & \\
Phyllanthus amarus leaf extract & $40-50 \mathrm{~nm}$ & {$[11]$} \\
Adalodakam leaf extract & $44 \mathrm{and} 66 \mathrm{~nm}$ & {$[38]$} \\
Ananas comosus (L.) peel extract & $10-34 \mathrm{~nm}$ & {$[39]$} \\
Yucca gloriosa leaf extract & $35 \mathrm{~nm}$ & This work \\
\hline
\end{tabular}
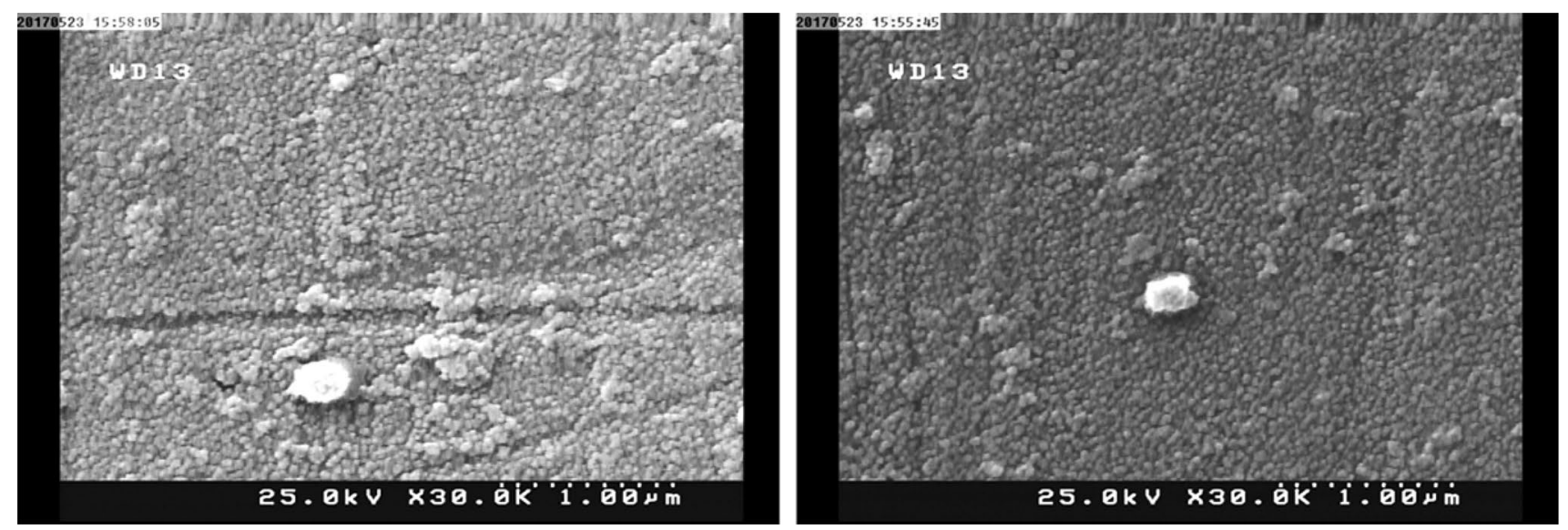

of the peak with the maximum intensity in half height, $d$ is the thickness of the crystal, and $\theta$ is the diffraction angle [35-37]. The results showed a size of $35 \mathrm{~nm}$ for $\mathrm{MnO}_{2}$ nanoparticles. For comparative, size of green synthesized Mn NPs via different plants is provided in Table 4.

\section{FESEM and TEM analyses}

FESEM (HITACHI, S-4160) images were carried out based on the morphology surface study. The synthesized $\mathrm{MnO}_{2}$ NPs were clean and spherical in shape [40, 41]. The FESEM micrographs in Fig. 6 clearly illustrate well dispersed and spherical $\mathrm{MnO}_{2} \mathrm{NPs}$ developed with $Y$. gloriosa aqueous extract. The $\mathrm{MnO}_{2}$ NPs instead of having a compressed packed structure display the much open and semi-linear structure [42].

The structure and morphology of the $\mathrm{MnO}_{2} \mathrm{NPs}$ at higher resolution are shown in the TEM images (Fig. 7). The images clearly show the attendance of secondary material around $\mathrm{MnO}_{2}$ which indicated to bioorganic compounds that synthesized and stabilized the spherical $\mathrm{MnO}_{2} \mathrm{NPs}$.

\section{Conclusions}

Yucca gloriosa leaf extract was a suitable reducing agent for the synthesis of the $\mathrm{MnO}_{2}$ nanoparticles. The effects of three factors that are $\mathrm{pH}$ of the metallic solution, time, and the extract ratio were studied and optimized using RSM. The concentration of the extract was the most effective parameter and then time, and also $\mathrm{pH}$ did not have much effect on absorbance. The $\mathrm{MnO}_{2}$ NPs synthesized using $Y$. gloriosa leaf extract and turmeric extract were used as a reducing and stabilizing agent, respectively. The $\mathrm{MnO}_{2}$ NPs were characterized using XRD, FESEM, and TEM analyses. XRD study confirms the synthesized of the $\mathrm{MnO}_{2} \mathrm{NPs}$ with around

Fig. 6 FESEM images of synthesized $\mathrm{MnO}_{2} \mathrm{NPs}$

\footnotetext{
Fig. 6 FESEM images of synthesized $\mathrm{MnO}_{2} \mathrm{NPs}$
} 

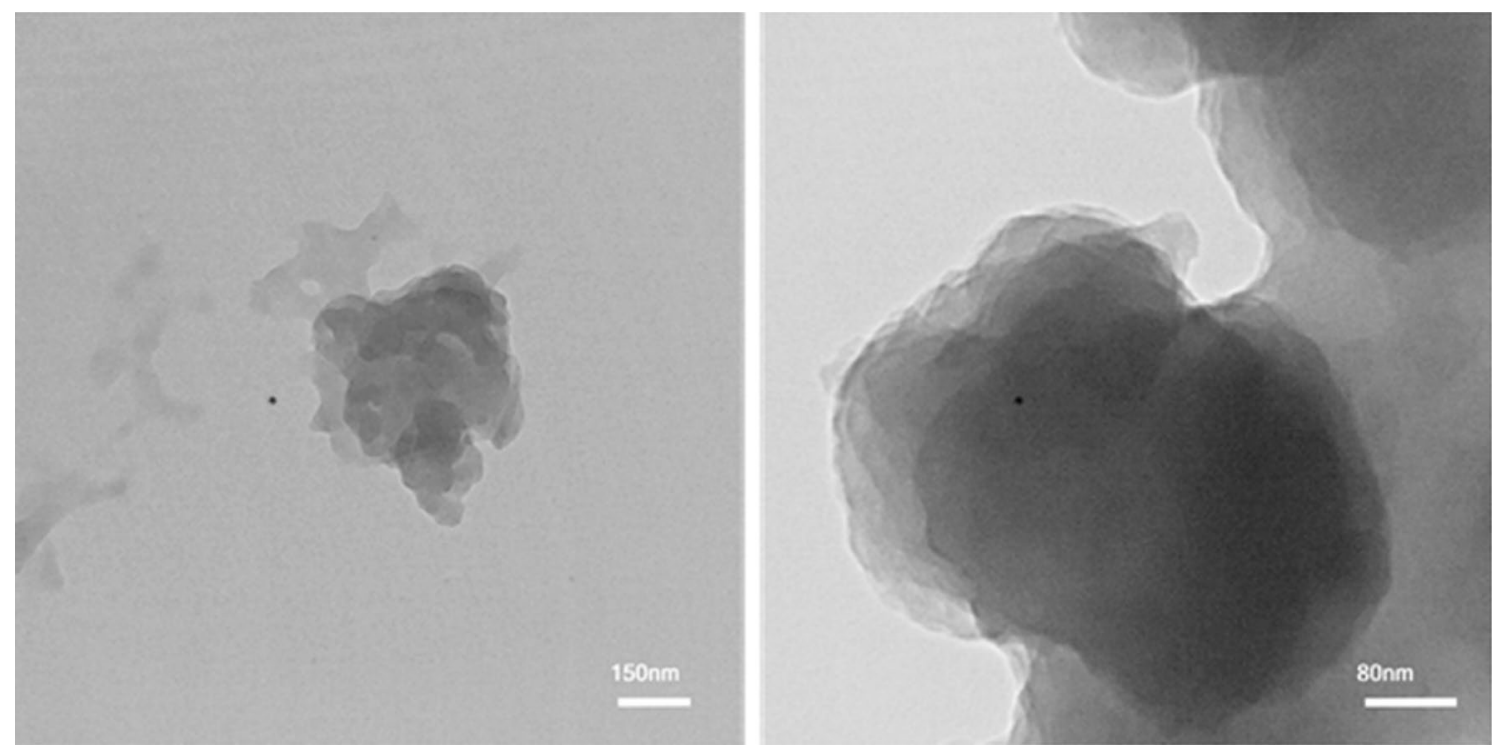

Fig. 7 TEM images of synthesized $\mathrm{MnO}_{2} \mathrm{NPs}$

size of $32 \mathrm{~nm}$. The synthesis using plant extract is feasible by an easy reaction at ambient temperature and pressure, without the need of using catalysts, cast, or costly material. The degradation ability of the $Y$. gloriosa was demonstrated by $\mathrm{MnO}_{2} \mathrm{NPs}$ synthesis. As a suggestion, Mn oxides can be employed in imaging contrast agents, magnetic storage devices, water treatment, and purification, due to their privileged physical and chemical properties.

Open Access This article is distributed under the terms of the Creative Commons Attribution 4.0 International License (http://creativeco mmons.org/licenses/by/4.0/), which permits unrestricted use, distribution, and reproduction in any medium, provided you give appropriate credit to the original author(s) and the source, provide a link to the Creative Commons license, and indicate if changes were made.

\section{References}

1. Abbasi, Z., Feizi, S., Taghipour, E., Ghadam, P.: Green synthesis of silver nanoparticles using aqueous extract of dried Juglans regia green husk and examination of its biological properties. Green Process. Synth. (2017). https://doi.org/10.1515/gps-2016-0108

2. Hoseinpour, V., Ghaemi, N.: Novel $\mathrm{ZnO}-\mathrm{MnO}_{2}-\mathrm{Cu}_{2} \mathrm{O}$ triple nanocomposite: facial synthesis, characterization, antibacterial activity and visible light photocatalytic performance for dyes degradation-a comparative study. Mater. Res. Express. 5, 85012 (2018). https://doi.org/10.1088/2053-1591/aad2c6

3. Jalal, R., Goharshadi, E.K., Abareshi, M., Moosavi, M., Yousefi, A., Nancarrow, P.: ZnO nanofluids: green synthesis, characterization, and antibacterial activity. Mater. Chem. Phys. 121, 198-201 (2010). https://doi.org/10.1016/j.matchemphys.2010.01.020

4. Sathiyamoorthi, E., Moon, S.A., Alkotaini, B., Kim, B.S., Salunke, B.K.: Biological synthesis of manganese dioxide nanoparticles by
Kalopanax pictus plant extract. IET Nanobiotechnol. 9, 220-225 (2015). https://doi.org/10.1049/iet-nbt.2014.0051

5. Dong, C., Cao, C., Zhang, X., Zhan, Y., Wang, X., Yang, X., Zhou, K., Xiao, X., Yuan, B.: Wolfberry fruit (Lycium barbarum) extract mediated novel route for the green synthesis of silver nanoparticles. Optik Int. J. Light Electron Opt. 130, 162-170 (2017). https://doi.org/10.1016/j.ijleo.2016.11.010

6. Sinha, A., Singh, V.N., Mehta, B.R., Khare, S.K.: Synthesis and characterization of monodispersed orthorhombic manganese oxide nanoparticles produced by Bacillus sp. cells simultaneous to its bioremediation. J. Hazard. Mater. 192, 620-627 (2011). https ://doi.org/10.1016/j.jhazmat.2011.05.103

7. Kumar, V., Singh, K., Panwar, S., Mehta, S.K.: Green synthesis of manganese oxide nanoparticles for the electrochemical sensing of p-nitrophenol. Int. Nano Lett. 7, 123-131 (2017). https://doi. org/10.1007/s40089-017-0205-3

8. Zhang, H., Wu, A., Fu, H., Zhang, L., Liu, H., Zheng, S., Wan, $\mathrm{H}$., $\mathrm{Xu}, \mathrm{Z}$.: Efficient removal of $\mathrm{Pb}(<\mathrm{scp}>\mathrm{ii}</ \mathrm{scp}>)$ ions using manganese oxides: the role of crystal structure. RSC Adv. 7, 41228-41240 (2017). https://doi.org/10.1039/C7RA05955H

9. Jayandran, M., Haneefa, M., Balasubramanian, V.: Green synthesis and characterization of Manganese nanoparticles using natural plant extracts and its evaluation of antimicrobial activity. J. Appl. Pharm. Sci. 1, 105-110 (2015). https://doi.org/10.7324/ JAPS.2015.501218

10. Souri, M., Hoseinpour, V., Shakeri, A., Ghaemi, N.: Optimisation of green synthesis of $\mathrm{MnO}$ nanoparticles via utilising response surface methodology. IET Nanobiotechnol. 12, 822-827 (2018). https://doi.org/10.1049/iet-nbt.2017.0145

11. Prasad, K.S., Patra, A.: Green synthesis of $\mathrm{MnO} 2$ nanorods using Phyllanthus amarus plant extract and their fluorescence studies. Green Process. Synth. 6, 1-7 (2017). https://doi.org/10.1515/ gps-2016-0166

12. Maleki, A., Akbarzade, A.R., Bhat, A.R.: Green synthesis of polyhydroquinolines via MCR using $\mathrm{Fe}_{3} \mathrm{O}_{4} / \mathrm{SiO}_{2}-\mathrm{OSO}_{3} \mathrm{H}$ nanostructure catalyst and prediction of their pharmacological and biological activities by PASS. J. Nanostruct. Chem. 7, 309-316 (2017). https://doi.org/10.1007/s40097-017-0240-7 
13. Sangeetha, G., Rajeshwari, S., Venckatesh, R.: Green synthesis of zinc oxide nanoparticles by aloe barbadensis miller leaf extract: structure and optical properties. Mater. Res. Bull. 46, 2560-2566 (2011). https://doi.org/10.1016/j.materresbull.2011.07.046

14. Hoseinpour, V., Souri, M., Ghaemi, N.: Green synthesis, characterisation, and photocatalytic activity of manganese dioxide nanoparticles. Micro Nano Lett. (2018). https://doi.org/10.1049/ $\mathrm{mnl} .2018 .5008$

15. Dang, T.-D., Cheney, M.A., Qian, S., Joo, S.W., Min, B.-K.: A novel rapid one-step synthesis of manganese oxide nanoparticles at room temperature using poly(dimethylsiloxane). Ind. Eng. Chem. Res. 52, 2750-2753 (2013). https://doi.org/10.1021/ie302971g

16. Hoseinpour, V., Ghaemi, N.: Green synthesis of manganese nanoparticles: applications and future perspective-a review. J. Photochem. Photobiol. B 189, 234-243 (2018). https://doi. org/10.1016/j.jphotobiol.2018.10.022

17. Hassan, S.S.M., El Azab, W.I.M., Ali, H.R., Mansour, M.S.M.: Green synthesis and characterization of $\mathrm{ZnO}$ nanoparticles for photocatalytic degradation of anthracene. Adv. Nat. Sci. Nanosci. Nanotechnol. 6, 45012 (2015). https://doi.org/10.1088/20436262/6/4/045012

18. Vidya, C., Manjunatha, C., Chandraprabha, M.N., Rajshekar, M., Mal, A.R.: Hazard free green synthesis of $\mathrm{ZnO}$ nano-photocatalyst using Artocarpus heterophyllus leaf extract for the degradation of Congo red dye in water treatment applications. J. Environ. Chem. Eng. 5, 3172-3180 (2017). https://doi.org/10.1016/j. jece. 2017.05 .058

19. Souri, M., Shakeri, A.: Comparison of microwave and ultrasound assisted extraction methods on total phenol and tannin content and biological activity of Dittrichia graveolens (L.) GREUTER and its optimisation by response surface methodology. Curr. Bioact. Compd. 14, 23 (2018). https://doi.org/10.2174/157340721466618 0730110830

20. Parashar, V., Parashar, R., Sharma, B., Pandey, A.C.: Parthenium leaf extract mediated synthesis of silver nanoparticles: a novel approach towards weed utilization. Digest J. Nanomater. Biostruct. 4, 45-50 (2009)

21. Kumar, V., Singh, D.K., Mohan, S., Gundampati, R.K., Hasan, S.H.: Photoinduced green synthesis of silver nanoparticles using aqueous extract of Physalis angulata and its antibacterial and antioxidant activity. J. Environ. Chem. Eng. 5, 744-756 (2017). https ://doi.org/10.1016/j.jece.2016.12.055

22. Hoseinpour, V., Souri, M., Ghaemi, N., Shakeri, A.: Optimization of green synthesis of $\mathrm{ZnO}$ nanoparticles by Dittrichia graveolens (L.) aqueous extract. Health Biotechnol. Biopharma. 1, 39-49 (2017)

23. Bar, H., Bhui, D.K., Sahoo, G.P., Sarkar, P., De, S.P., Misra, A.: Green synthesis of silver nanoparticles using latex of Jatropha curcas. Colloids Surf. A 339, 134-139 (2009). https://doi. org/10.1016/j.colsurfa.2009.02.008

24. Favel, A., Kemertelidze, E., Benidze, M., Fallague, K., Regli, P.: Antifungal activity of steroidal glycosides from Yucca gloriosa L. Phytother. Res. 19, 158-161 (2005). https://doi.org/10.1002/ ptr.1644

25. Bassarello, C., Bifulco, G., Montoro, P., Skhirtladze, A., Benidze, M., Kemertelidze, E., Pizza, C., Piacente, S.: Yucca gloriosa: a source of phenolic derivatives with strong antioxidant activity. J. Agric. Food Chem. 55, 6636-6642 (2007). https://doi. org/10.1021/jf071131n

26. Bazrafshan, A.A., Hajati, S., Ghaedi, M.: Synthesis of regenerable $\mathrm{Zn}(\mathrm{OH}) 2$ nanoparticle-loaded activated carbon for the ultrasound-assisted removal of malachite green: optimization, isotherm and kinetics. RSC Adv. 5, 79119-79128 (2015). https:// doi.org/10.1039/C5RA11742A

27. Arulkumar, M., Sathishkumar, P., Palvannan, T.: Optimization of Orange $\mathrm{G}$ dye adsorption by activated carbon of Thespesia populnea pods using response surface methodology. J. Hazard. Mater. 186, 827-834 (2011). https://doi.org/10.1016/j.jhazm at.2010.11.067

28. García-Cabeza, A.L., Ray, L.P., Marín-Barrios, R., Ortega, M.J., Moreno-Dorado, F.J., Guerra, F.M., Massanet, G.M.: Optimization by response surface methodology (RSM) of the KharaschSosnovsky oxidation of valencene. Org. Process Res. Dev. 19, 1662-1666 (2015). https://doi.org/10.1021/op5002462

29. Sasani Ghamsari, M., Alamdari, S., Han, W., Park, H.-H.: Impact of nanostructured thin $\mathrm{ZnO}$ film in ultraviolet protection. Int. J. Nanomed. 12, 207-216 (2016). https://doi.org/10.2147/IJN.S118637

30. Jain, M., Garg, V.K., Kadirvelu, K.: Investigation of $\mathrm{Cr}(\mathrm{VI})$ adsorption onto chemically treated Helianthus annuus: optimization using response surface methodology. Bioresour. Technol. 102, 600-605 (2011). https://doi.org/10.1016/j.biortech.2010.08.001

31. Bezerra, M.A., Santelli, R.E., Oliveira, E.P., Villar, L.S., Escaleira, L.A.: Response surface methodology (RSM) as a tool for optimization in analytical chemistry. Talanta 76, 965-977 (2008). https://doi.org/10.1016/j.talanta.2008.05.019

32. Hamsaveni, D.R., Prapulla, S.G., Divakar, S.: Response surface methodological approach for the synthesis of isobutyl isobutyrate. Process Biochem. 36, 1103-1109 (2001). https://doi.org/10.1016/ S0032-9592(01)00142-X

33. Yallappa, S., Manjanna, J., Sindhe, M.A., Satyanarayan, N.D., Pramod, S.N., Nagaraja, K.: Microwave assisted rapid synthesis and biological evaluation of stable copper nanoparticles using T. arjuna bark extract. Spectrochim. Acta Part A Mol. Biomol. Spectrosc. 110, 108-115 (2013). https://doi.org/10.1016/j.saa.2013.03.005

34. Christensen, L., Vivekanandhan, S., Misra, M., Kumar Mohanty, A.: Biosynthesis of silver nanoparticles using Murraya koenigii (Curry Leaf): an investigation on the effect of broth concentration in reduction mechanism and particle size. Adv. Mater. Lett. 2, 429-434 (2011). https://doi.org/10.5185/amlett.2011.4256

35. Khataee, A., Sheydaei, M., Hassani, A., Taseidifar, M., Karaca, S.: Sonocatalytic removal of an organic dye using TiO2/montmorillonite nanocomposite. Ultrason. Sonochem. 22, 404-411 (2015). https://doi.org/10.1016/j.ultsonch.2014.07.002

36. Prabhu, Y.T., Rao, K.V., Kumar, V.S.S., Kumari, B.S.: X-ray analysis by Williamson-Hall and size-strain plot methods of $\mathrm{ZnO}$ nanoparticles with fuel variation. World J. Nano Sci. Eng. 4, 21-28 (2014). https://doi.org/10.4236/wjnse.2014.41004

37. Uvarov, V., Popov, I.: Metrological characterization of X-ray diffraction methods at different acquisition geometries for determination of crystallite size in nano-scale materials. Mater. Charact. 85, 111-123 (2013). https://doi.org/10.1016/j.matchar.2013.09.002

38. Prasad, A.S.: Green synthesis of nanocrystalline manganese (II, III) oxide. Mater. Sci. Semicond. Process. 71, 342-347 (2017). https://doi.org/10.1016/j.mssp.2017.08.020

39. Asaikkutti, A., Bhavan, P.S., Vimala, K., Karthik, M., Cheruparambath, P.: Dietary supplementation of green synthesized manganese-oxide nanoparticles and its effect on growth performance, muscle composition and digestive enzyme activities of the giant freshwater prawn Macrobrachium rosenbergii. J. Trace Elem. Med. Biol. 35, 7-17 (2016). https://doi.org/10.1016/j.jtemb.2016.01.005

40. Jayaseelan, C., Rahuman, A.A., Kirthi, A.V., Marimuthu, S., Santhoshkumar, T., Bagavan, A., Gaurav, K., Karthik, L., Rao, K.V.B.: Novel microbial route to synthesize $\mathrm{ZnO}$ nanoparticles using Aeromonas hydrophila and their activity against pathogenic bacteria and fungi. Spectrochim. Acta Part A Mol. Biomol. Spectrosc. 90, 78-84 (2012). https://doi.org/10.1016/j.saa.2012.01.006

41. Hoseinpour, V., Ghaee, A., Vatanpour, V., Ghaemi, N.: Surface modification of PES membrane via aminolysis and immobilization of carboxymethylcellulose and sulphated carboxymethylcellulose for hemodialysis. Carbohyd. Polym. 188, 37-47 (2018). https:// doi.org/10.1016/j.carbpol.2018.01.106 
42. Gunalan, S., Sivaraj, R., Venckatesh, R.: Aloe barbadensis Miller mediated green synthesis of mono-disperse copper oxide nanoparticles: optical properties. Spectrochim. Acta Part A Mol. Biomol. Spectrosc. 97, 1140-1144 (2012). https://doi.org/10.1016/j. saa.2012.07.096
Publisher's Note Springer Nature remains neutral with regard to jurisdictional claims in published maps and institutional affiliations. 